Article

\title{
The Evolutions, Transformations, and Adaptations in Beirut's Public Spaces
}

\author{
Christine Mady \\ Department of Architecture, Notre Dame University-Louaize, Lebanon; christine.mady@ndu.edu.lb
}

Submitted: 27 July 2021 | Accepted: 22 September 2021 | Published: 23 February 2022

\begin{abstract}
Beirut, Lebanon, has been a nexus for the east and west, has undergone episodes of conflict including the civil war between 1975 and 1989, and still witnesses instability to the present. This status has affected its everyday life practices, particularly as manifested in its public spaces. Over time, Beirut's population has reflected the ability to adapt to living with different states of public spaces; these include embracing new public space models, adjusting to living in the war-time period with annihilated public spaces, and establishing a reconnaissance with post-war reintroduced, securitized, or temporary public spaces. Lefebvre's space production triad serves to distinguish among spaces introduced through planning tools, from spaces appropriated through immaterial space-markers, or spaces established through social practices. This article provides an overview of the evolution of Beirut's public spaces, starting with the medieval city and through into the 19th century, before examining the impact of instability and the conditions leading to the emergence of social spaces in the post-war period. It particularly highlights public spaces after 2005-when civic activism played an important role in raising awareness on the right to inclusive public space-by referring to literature, conducting interviews with public space protagonists, and addressing a questionnaire survey to inhabitants. The cases of Martyrs Square, Damascus Road, and the Pine Forest are presented, among other spaces in and around Beirut. The article reflects on the ability of some public spaces to serve as tools for social integration in a society that was segregated in the bouts of Beirut's instability.
\end{abstract}

\section{Keywords}

Beirut; Damascus Road; Lefebvre; Martyrs Square; Pine Forest; public space; social integration

\section{Issue}

This article is part of the issue "Urbanisation, Crisis, and Resilience: The Multiple Dimensions of Urban Transformation in Beirut, Lebanon" edited by Liliane Buccianti-Barakat (Saint Joseph University) and Markus Hesse (University of Luxembourg).

(C) 2022 by the author(s); licensee Cogitatio (Lisbon, Portugal). This article is licensed under a Creative Commons Attribution 4.0 International License (CC BY).

\section{Introduction}

This article aims to investigate the evolution of public spaces in Beirut, Lebanon, starting from the medieval city and through into 19th-century changes. It explores transformations and adaptations of Beirut's public spaces caused by the civil war (1975-1989), with social divides and consecutive instabilities to date. Public spaces are "meeting places," which influence how people experience cities (Rydin, 2011, p. 112). Particularly in divided societies, the "management of co-existence" in public spaces to avoid alienation and exclusion requires an understanding of contextual social relations, different values, and spatial practices (Healey, 1997/2006, p. 111; Makakavhule \& Landman, 2020).

Public spaces have been studied in terms of their morphology, activities, users, regulation, and management (Carmona et al., 2008; Carr et al., 1992; Gehl, 1996; Madanipour, 2003). Morphologically, in addition to parks and squares, streets are the basic public space form. Streets are places of everyday encounters, festivities and protests, and the loci for social and political activities (Carr et al., 1992; Gehl \& Gemzøe, 1996; Hou \& Knierbein, 2017). With their surroundings, streets are mnemonic spaces, which generate, preserve, and perpetuate collective memories or "narratives and commemorative 
practices" (Hebbert, 2005, p. 592; Larkin, 2012, p. 13). In terms of public space uses and activities, these include necessary, optional, or social ones, which are dynamic and change through time (Brown, 2006, p. 22; Carr et al., 1992; Gehl, 1996; Landman, 2016). Activities are governed by social conventions, economic and legal practices including direct and indirect control mechanisms, which could lead to exclusion (Loukaitou-Sideris \& Banerjee, 1998; Papachristou \& Rosas-Casals, 2019; Staeheli \& Thompson, 1997). Public spaces are relational, embedded in their contextual, social, political, and cultural traits (Knierbein \& Tornaghi, 2015). Those that facilitate social practices and the coexistence of differences simultaneously affect and are shaped by everyday life, reflecting the society producing them (Knierbein, 2015; Lefebvre, 1991; Madanipour, 2003, p. 146).

Tying the importance of providing public spaces that enable social practices and the coexistence of differences in Beirut, Lefebvre's (1991) space production triad serves to explore the evolution, transformations, and adaptations of its public spaces. How were Beirut's public spaces produced throughout history? What is the impact of instability on these spaces? What conditions led to the emergence of social spaces? Research content for this article derives from a desk-based literature review on Beirut; several interviews conducted during 2020 and 2021 with public space protagonists, specifically in relation to the informal public transportation system, the Beirut Pine Forest; and one public space designed in the neighborhood of Naba'a in an eastern suburb. Also, an online questionnaire survey was conducted in September 2021, which provided an indicative sample of inhabitants' perspectives on Beirut's public spaces. The 122 responses yielded information on frequenting spaces along the war-time demarcation line, the availability of public spaces in various neighborhoods within Beirut and Greater Beirut, the activities performed in these spaces, and perceptions on their symbolism.

\section{The Production of Public Space}

In explaining social space, Lefebvre (1991) referred to space representations, representational spaces, and spatial practices as the three constituent components. These are respectively qualified as conceived, lived, and perceived spaces. Lefebvre (1991, p. 42) emphasized that space production requires tracing the historical evolution, considering that relations among the three components include "interconnections, distortions, displacements." "Representations of space" are spaces designated on maps by built environment professionals, through acquired "knowledge and ideology," and an official authority's decision (Lefebvre, 1991, pp. 38-42). Written in 1974, Lefebvre's reference was to modernist, top-down, land zoning, and car-oriented planning, which Rydin (2011) explained as comprehensive-often based on professional judgement, existing norms, and dominant views-resulting in plans fixing public space loca- tions. Without users' participation, the plans become tools for meeting influential actors' agendas, such as investing in profitable central locations, while neglecting marginal ones, despite the latter's importance in people's daily practices (Madanipour, 2004). Designed public spaces are often highly programmed, more limited in terms of appropriation and improvisation, and less responsive to changing social needs (Gastil \& Ryan, 2004; Knierbein, 2015; Kostof, 1992). In this sense, Lefebvre emphasized the importance of opposing approaches that could deter the production of social spaces (Cutts \& Minn, 2018). This grounds the quest for different provision mechanisms, such as allowing for versatile, temporary spaces, whose socio-spatial role increases in times of crises (Franck \& Stevens, 2007; Haydn \& Temel, 2006; Landman, 2020). "Representational spaces" are spaces that are lived, affecting how users interact with and within them, by attributing meanings through signs, symbols, images, language, or even memories (Lefebvre, 1991, p. 39). Representational space is dynamic and fluid, it intertwines with spatial practices situationally and relationally (Lefebvre, 1991, p. 42). In divided societies, conflicting meanings, values, and expressions could dominate and be perpetuated across generations, thus excluding some users from these spaces (Healey, 1997/2006). Dismantling such representational spaces requires suitable conditions to facilitate social integration beyond kin or the dominant power (Healey, 1997/2006). This is possible through public space provision with place-based identities, interest-based identities, consensus-oriented processes, and the institutionalization of the collaborating groups, as identified by Mady and Chettiparamb (2016, p. 296). "Spatial practices" refer to everyday interactions unfolding in time, with and in a specific context, among people and objects (Lefebvre, 1991, p. 38). Social practices require social spaces, which are constituted when the spatial, social, and mental components interact and coexist under "favorable circumstances": If one is missing, "oppositions, contrasts, or antagonisms" might arise (Lefebvre, 1991, pp. 39-40).

Lefebvre's triad has been widely used in various disciplines (Dorsch, 2013), more specifically in relation to public space to explain, for example, its resistance to commodification (Tornaghi, 2015), its co-production and reshaping (Wolf \& Mahaffey, 2016), factors influencing its variations in Qatar (Salama \& Wiedmann, 2013), or its state in neoliberal urban dynamics and regeneration in South Africa (Landman, 2019; Nkooe, 2018). More specifically, in the context of divided cities, the triad served to explain power relations and the construction of urban divides, or how lived space could counter divisions reinforced by conceived space (Nagle, 2009; Véron, 2016). Regarding Beirut, the triad has been used to explain the promotion of public space identity (Saksouk-Sasso, 2015) and people's role in shaping reconstructed urban spaces (Deeb \& Harb, 2013; Fawaz, 2014). In this article, Lefebvre's triad is used to 
examine the historical evolution of the three spatial components, whether the domination or absence of one has affected the role of urban spaces in people's everyday lives, and whether "favorable" conditions resulted in social space production.

\section{Beirut's Public Spaces}

This section examines the political and socio-cultural evolution along with the tools and conditions that led to Beirut's public space production, starting from the medieval city with its spontaneous urban development and concluding with the end of the civil war (Figure 1). It is important to note that Beirut witnessed a series of cascading planning approaches from one era to another, with transitions, continuities, and disruptions, and actors involving the governing authorities and the represented prominent local communities, as will be explained in the following sections.

\subsection{Utilitarian Places, Imported Models, and Market-Led Development}

The medieval, walled port city of Beirut was open to external influences, with an internal religious and cultural mix, leading to a complex social structure. The city was functionally partitioned in relation to the port and the main road, later named Damascus Road, linking it to the hinterland. Inside, Christian and Muslim communities lived in quarters, each with their own center and public spaces (M. Davie, 2001). Formed through customs and traditions, public spaces were "lived" and "perceived," functional, and utilitarian gathering spaces, as reflected in their names (M. Davie, 2001). The squares or sahas were geometrically irregular spaces at crossroads and some served as marketplaces or souqs (M. Davie, 1999, 2001). Souqs were distributed according to their merchandise and the more strategically located ones were surrounded by several public amenities (M. Davie, 2001,

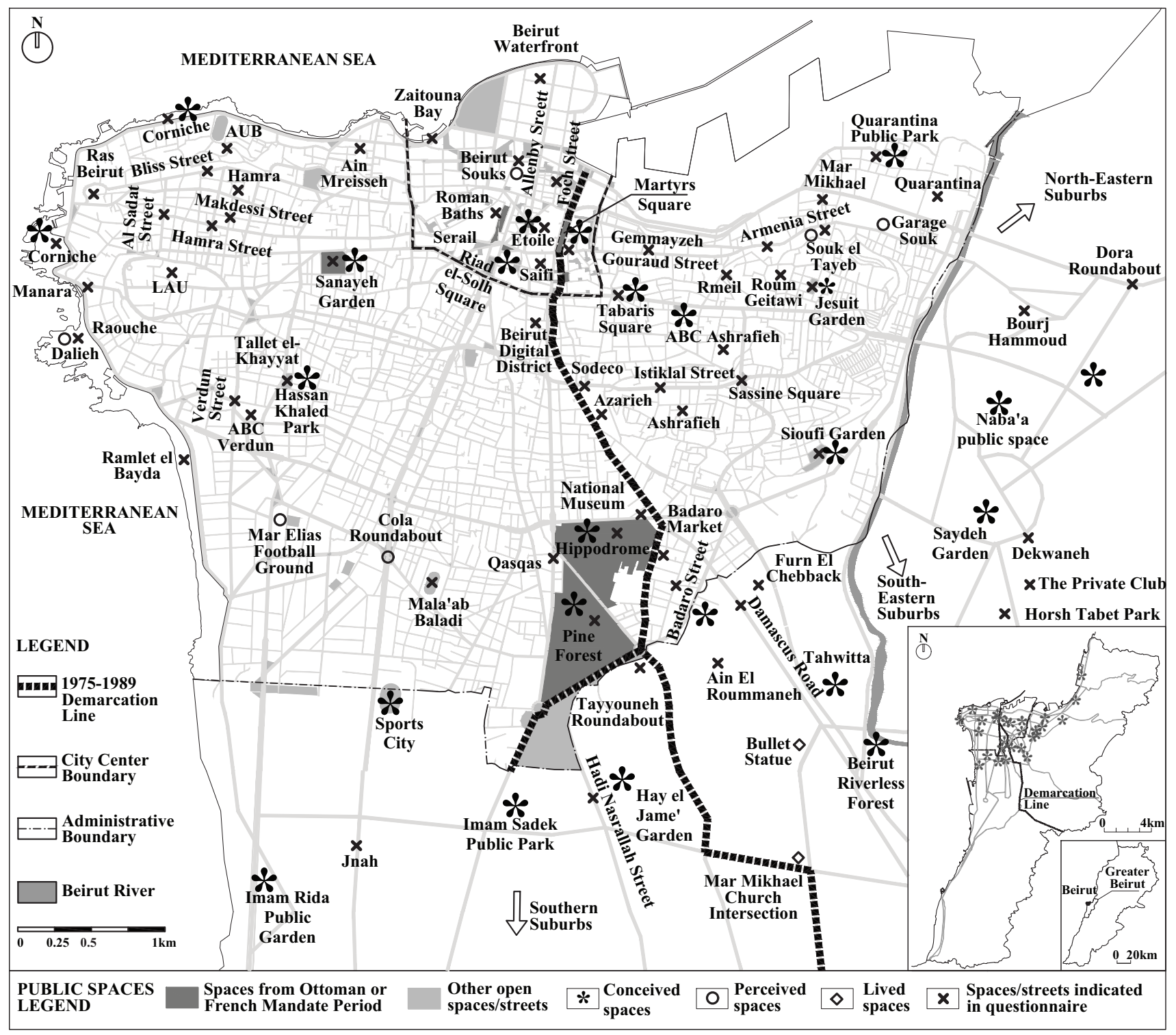

Figure 1. Beirut's public spaces through time and as indicated by questionnaire survey respondents. 
p. 30). Other sahas were linked to churches and mosques serving different religious communities (Öztürk, 2006). Transitioning from the medieval city meant the persistence of "social practices" while spaces were gradually "conceived" according to modernization plans and "lived" according to the spirit of the age.

The first half of the 19th century marked Beirut's expansion beyond the walls, as it became the third most important Mediterranean port following Alexandria and Izmir (M. Davie, 2001; Khalaf, 2006; Saliba, 1998). Its new position as a global trade center influenced ideologies, economic processes, and social structures, giving Beirut a "European" atmosphere with some residents' newly adopted lifestyles, as evident in their public space practices (M. Davie, 2001; Khalaf, 2006, p. 52). Transformations continued in the second half of the 19th century, with Ottoman power reflected at various scales. Between 1857 and 1903, these included infrastructure projects such as the port modernization, the construction of Damascus Road, and the port railway. On the city scale, urban expansion included the demolition of the city walls and the emergence of new neighborhoods, with infrastructure including the seaside promenade or Corniche to the west, schools, religious, and administrative buildings, including the Serail, in 1853, and the neo-Ottoman style clocktower, in 1895, thus stamping Beirut with Ottoman symbolism (M. Davie, 2001; Dumont, 2013; Hanssen, 2005; Khalaf, 2006; Tozoglu, 2019). These significant morphological transformations were possible through the "Tanzimat," in 1856, which instituted the municipality, urban codes, land regulation, and systematic planning to replace organically developed urbanism; this enabled responding to urban densification following the drastic population increase after 1860 due to unrest in Mount Lebanon and Aleppo (M. Davie, 2001; Dumont, 2013; Öztürk, 2006; Saliba, 1998). Similar to other Ottoman cities, the local notables as municipal members-including merchants and community and religious leaders equally representing the Christian and Muslim communities-collaborated in space production, as part of the "urban embellishment" (M. Davie, 2001; Dumont, 2013, p. 194; Tozoglu, 2019). Beirut's modern conceived, lived, and perceived spaces were shaped by political, economic, and social factors.

On the public space scale, until the demolition of the medieval fabric, new public spaces emerged alongside the medieval ones in Beirut's multiple centers (M. Davie, 2001, p. 29). The existing pluri-functional public spaces did not lend themselves to representing Ottoman power, which necessitated "conceiving" new spaces, for example, the Hamidiye, el-Sur, and the Sanayeh Garden. In 1862 and east of the city walls, the maydan-a rectangular space serving horsemen during the Mamluk period (1291-1516)-was joined to the city and transformed into the Hamidiye Garden, renamed Union Square in 1908, then Bourj Square, and lastly Martyrs Square (M. Davie, 2001; Keilo, 2020; Khalaf, 2006). The Hamidiye reflected Ottoman power in its design, military parades, and demonstrations (M. Davie, 2001, p. 31). Over time, it became a gathering place for various groups with economic, recreational, and social activities; during the French mandate, it became "the meeting place of the upper bourgeoisie and newly affluent social groups" (Khalaf, 2006, p. 195; Öztürk, 2006). South-west of the city walls, albeit at a different scale and with an irregular form, sahat el-Sur was transformed from a marketplace with a coffeeshop serving the low-income class into an official public space with a fountain, used for parades and commemorations (M. Davie, 2001; Hanssen, 2005; Hindi, 2015; Khalaf, 2006). Though not centrally located, these two spaces became the city's lungs, serving the authorities and various socio-economic, ethnic, and religious communities (M. Davie, 2001; Khalaf, 2006). Furthermore, as part of connecting Ottoman territories to global economies, and with diplomatic and missionary activities locating in Beirut, the city experienced the rise of banking, commercial, and real estate development projects where public spaces became development tools (Dumont, 2013; Khalaf, 2006; Tozoglu, 2019). West of the medieval city, the Sanayeh Garden, with the vocational school established in 1905, served as a tool for developing in its vicinity businesses and religiously mixed residential projects for the "notable urban bourgeoisie" by increasing the location attractiveness and raising land value (Khalaf, 2006, p. 74).

Rather than having completely new projects, Beirut witnessed overlaps, disruptions, and continuities in its urban fabric over time, starting with Ottoman urban projects, disrupted by the French mandate (Hanssen, 1998). For the French, apart from new public spaces, modernizing the city included reconfiguring existing ones such as sahat el-Sur and Martyrs Square, continuing the Corniche and the demolition of the old souqs and garden houses, which started in 1915 and was completed in 1918 (Hanssen, 1998; Salam, 1998). The Haussmanian planning approach and their "mission civilisatrice" partly wiped away the Ottoman identity (Dumont, 2013; Öztürk, 2006). Planning was a tool for domination and the diffusion of modernist ideas, which impacted decision makers, urban planners, planning education, and the society at large (Verdeil, 2012). The 1927 and 1932 plans proposed a central square with radiating streets, flanked by official buildings, with the aim of establishing Beirut as a financial center, the "Paris of the East" (Dumont, 2013; Matsubara, 2016, p. 407; Öztürk, 2006). French ambitions were buttressed by a street naming system, which was akin to reinventing Beirut's identity (Keilo, 2020, p. 257). This system maintained local Christian and Muslim figure names as distributed in the eastern and western city parts, introduced new names, such as the central Place de l'Etoile Square, de Gaulle, Gouraud, Foch, and Allenby streets, but also renamed the Corniche to Avenue de Paris (Keilo, 2017, 2020). Beirut's complex social structure prevented the French "localism and swift Europeanization" scheme from fully imposing a new cultural identity, as 
local resistance continued despite the elites who served the French authorities (M. Davie, 2001; Dumont, 2013, p. 196; Öztürk, 2006). Even the 1942 Ecochard plan was opposed, modified, and only partly implemented, with the contributions of local planners marking the transition from a colonial era (Verdeil, 2012).

Constituted in 1943, the Republic of Lebanon was characterized by a free-market economy, a weak state overpowered by notable families and strong sectarian community identities, and a lack of civic belonging (Khalaf, 2006). The government initially adopted the French planning system, yet the 1963 Ecochard plan for Beirut and its suburbs was modified to prioritize road infrastructure as a form of nation building and to serve trade interests (Matsubara, 2016; Monroe, 2017; Salam, 1998; Tabet, 1996; Verdeil, 2011, 2012). Beirut's expansion was left to real estate developers in a laissez-faire approach, providing few new public spaces, often reduced to road medians and roundabouts or leftovers after planning (Salam, 1998). Despite some "representational" and "perceived" transformations including changing some public space names (Keilo, 2020), the "conceived" public spaces by the Ottomans and French resulted in obdurate spaces. These included several streets, the Corniche, Sanayeh Garden, Martyrs Square, and Riad el-Solh Square.

\subsection{Conflict, Annihilation, and Fragmentation}

Following internal and external conflicts, the civil war erupted in 1975 between various Lebanese politicosectarian parties; later there were interventions of foreign armed forces (Hanf, 1993; Khalaf, 2002; Traboulsi, 2012). The war had several implications on Beirut's public spaces. At the city scale, a demarcation line germinated from Martyrs Square, going along Damascus Road and south to the Pine Forest, splintering Beirut into east and west. This led to population displacement and segregation in the divided city parts with limited mobility across them. The demarcation line formed an inaccessible zone, a "no-man's land," a frontier that was intermittently crossed, a buffer having two backs facing each other, absent from everyday life, and its two extremes-Martyrs Square and the Pine Forest-slowly fading away from collective memory (Huybrechts, 1999, p. 216; Kabbani, 1998; Saliba, 1997; Tabet, 1996). The city center was destroyed, signifying the erasure of Beirut's cultural and collective memory (Tabet, 1996). Outside the center, fighting alienated the "familiar spaces of the city," including transportation terminals and public spaces, which were avoided (Khalaf, 2002, 2006; Nucho, 2016, p. 23; Tabet, 1996; Yahya, 1993). Beirut's divided parts were further fragmented along streets converted to militia frontiers, which generated multiple urban centers over time (M. F. Davie, 1993; Khalaf, 2006). These newly formed "lived" spaces were differentiated with militia space-markers, checkpoints, and barriers, which affected mobility across them and lim- ited inhabitants' daily practices to the confines of their communities (M. F. Davie, 1991, 1993; Khalaf, 2006; Nucho, 2016; Yahya, 1993). In 1989, the Taif Agreement marked the end of the war, while Lebanon continues to undergo intermittent instability to date. The war left a "fragmented city" with irreconcilable memories, commemorations of violent events, a publicly mistrusted weak state, dominant politico-sectarian leaders, and the prevalence of private real estate development (Albrecht, 2017, 2020; M. F. Davie, 1991, p. 2; Huybrechts, 1999; Khalaf, 2006).

\section{Drivers and Inhibitors of Social Space Production}

Post-war Beirut faced an imbalance among the limited "conceived," exclusive "lived," and scarce "perceived" public spaces, resulting in "oppositions, contrasts and antagonisms," which manifested at the metropolitan, city, and public space scales (Figure 2).

\subsection{Conceived, Perceived, and Lived Spaces}

Post-war reconstruction prioritized reviving existing "conceived" spaces by reconnecting the street network including the demarcation line, and replanning Beirut's center under the public-private partnership real estate company Solidere. The center's public spaces were no longer social spaces, the inhabitants' melting pot, similar to their pre-war role (Tabet, 1996). In contrast, initiatives by activists served to realize inclusive "perceived" spaces.

Dismantling the demarcation line excluded reinserting Martyrs Square and the Pine Forest in the city, maintaining them as deserted until 2005 and 2016, respectively. The fragmented polycentric city, with densifying east and west parts and expanding suburbswith changed social structures and politico-sectarian tensions-kept forming new frontiers (Bou Akar, 2012, 2018). These "lived" spaces of "different politicoreligious territories" were marked by monuments, signs, securitization, and stamped by collective memories, affecting everyday social practices (Ababsa, 2002; Fawaz et al., 2009, p. 181; Genberg, 2002; see Figure 3). On the one hand, mobility across these boundaries became a practice that differed according to "sectarian geographies," meaning that inhabitants moved mostly within rather than across community territories (Bollens, 2012; Monroe, 2011; Nucho, 2016, p. 3). On the other hand, securitization affected social interaction-physically, symbolically, or perceptuallyby sealing off public spaces, resulting in the emergence of "militarized landscapes" and limiting possibilities for encounter across the different communities (Fawaz et al., 2009, 2012; Nemeth, 2010, p. 2489; Nemeth \& Hollander, 2010).

The reconstructed city center with its highly controlled public spaces-Beirut souqs, Etoile (Nejmeh), Riad el-Solh, and streets-and circumscribing highways 


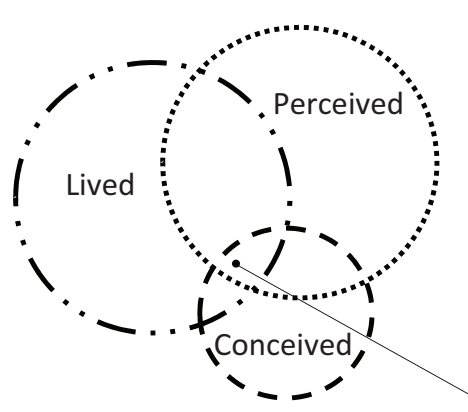

Medieval city

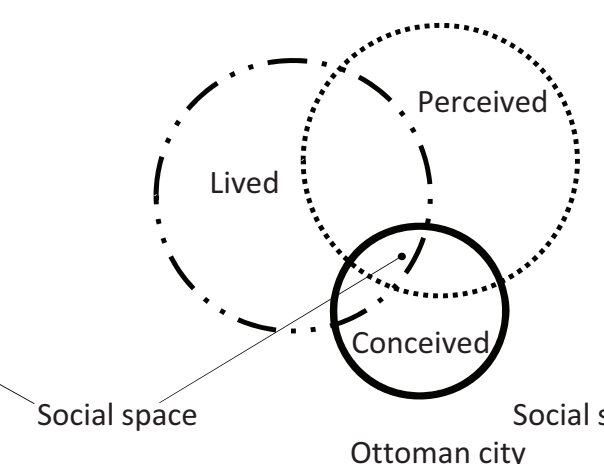

Ottoman city
Social space

Social space

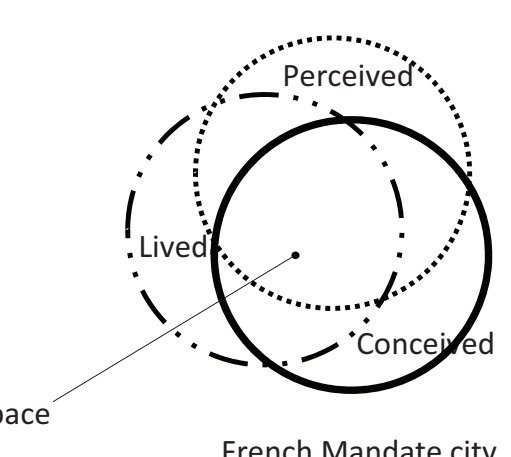

French Mandate city

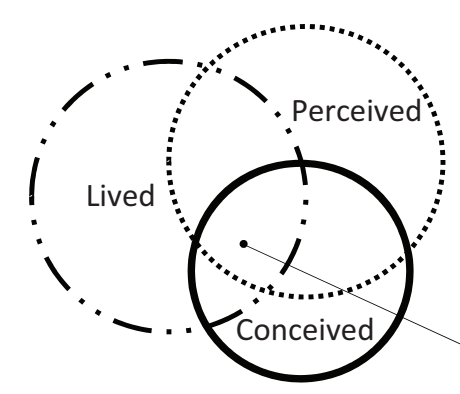

Republic capital city

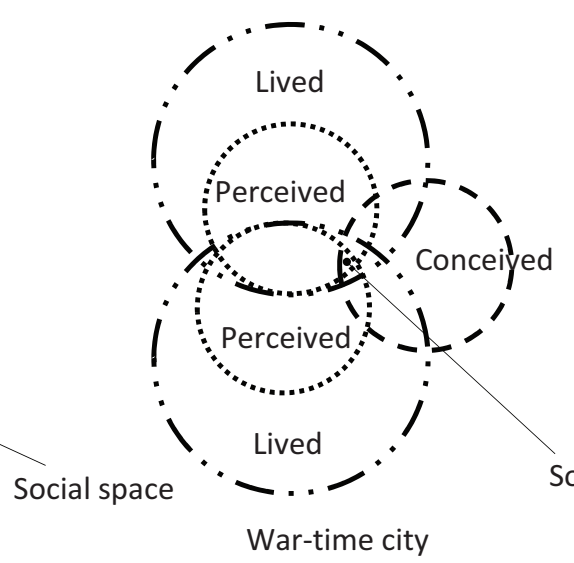

War-time city

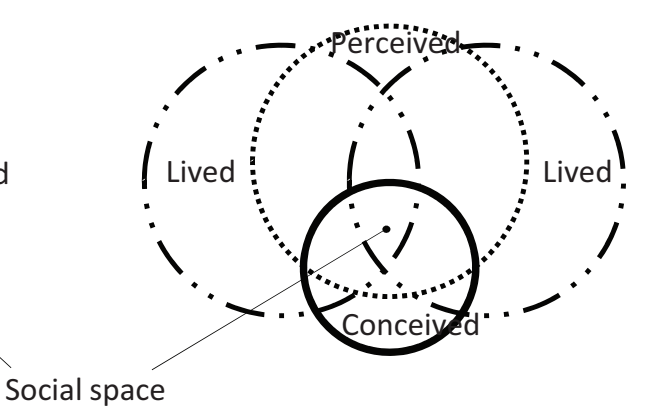

Post-war city

Figure 2. The space production triad in Beirut's various eras.

was disconnected from its surroundings physically, experientially, and perceptually, forming a sanitized area. This resulted in shifting most social practices from the center to the margins and strengthening the multiple "lived" spaces in and around Beirut, where communities continued to perform their daily practices within their comfort zones (Deeb \& Harb, 2013).

In the absence of a post-war plan for the Beirut metropolitan area, real estate development projects or some municipal ones resulted in fragmented and unco- ordinated "conceived" public spaces, scattered around rather than equitably distributed. Urban planning was also used as a tool by politico-sectarian parties to serve their communities and delineate their territories, consequently forming new frontiers (Bou Akar, 2018). These initiatives included the refurbishment of inherited public spaces such as the Corniche and Sanayeh Garden. Except for the Corniche, these central spaces were not "perceived" in people's daily lives due to control mechanisms, namely enclosure, limited access, and
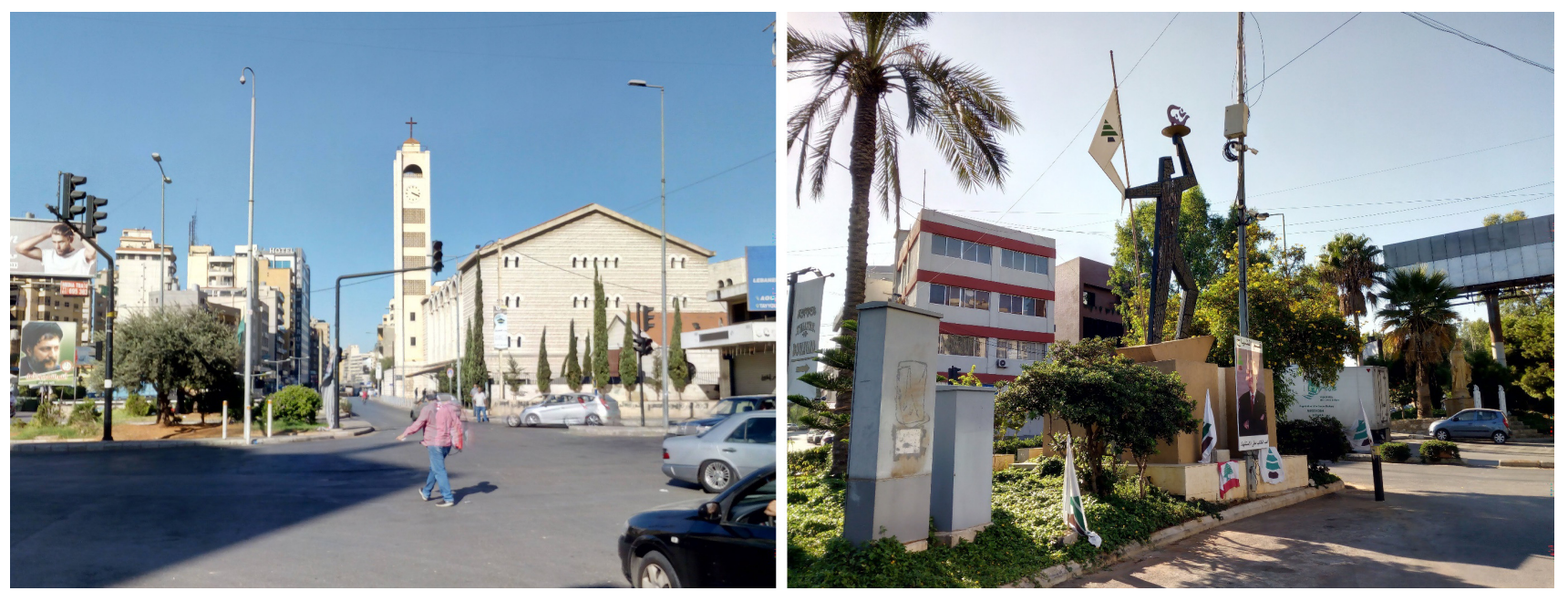

Figure 3. Representational spaces: Photographs of religious and political figures within designed road medians in Chiyah (see Figure 1 for the exact location). 
securitization. Marginal spaces were neglected in dense neighborhoods and refugee camps, which stood in contrast to the private open spaces of gated projects, disrupting the public domain alongside the "lived" spaces of various politico-sectarian groups, while the need was imminent for spaces that support not only the necessary and optional, but rather the social practices.

\subsection{The Production of Social Spaces}

Under the stated conditions, it was incumbent on third parties to provide inclusive public spaces, either by transforming obdurate "conceived" ones, or temporarily appropriating others. The year 2005 marked a turning point for Beirut's public spaces, with the reinstatement of a civic identity and an awakening of their role as catalysts for social integration (Khalaf, 2006). The "de-alienating" or re-programing of "conceived" public spaces formed a platform enabling diverse users to exchange different "local knowledge" (Healey, 1997/2006, p. 129; Knierbein, 2015, p. 54). From 2015 to 2019 , local activists organized themselves and reclaimed, transformed, and produced inclusive social spaces across Beirut and its suburbs. Examples include reclaiming Martyrs Square, the reopening of the Pine Forest, a new co-designed space in an eastern suburb, and other initiatives related to mobility, public access to the sea, temporary play areas, and marketplaces.

Beirut city center's "conceived" public spaces were tools for increasing the "exchange value" of nearby properties, while overlooking their "use value" (Lefebvre, 1991). They were highly controlled, underused spaces. Martyrs Square remained a void in the city, serving as car parking, until 2005, when it became the epicenter for civic activism, with recurring demonstrations including the solid waste management crisis in 2015 (Geha, 2019) and, more recently, the nationwide demonstrations in 2019. United in their aim to provide "accessible, inclusive, and safe" spaces, demonstrators "reconfigured, transformed, and revived" these spaces, while responding to physical, cultural, and social characteristics, to accommodate activities addressing different users (Sinno, 2020, pp. 199-200). In the absence of squares, this "placemaking" approach was evident elsewhere on streets, highways, and road intersections in and around Beirut (Sinno, 2020). Similarly, awareness raising, active collaboration, and building new shared meanings was the approach of the NGO Nahnoo, which started a campaign in 2011 to reopen the Pine Forest, a goal achieved in 2016 (Mady, 2018; Figure 4). Their second goal to remove "conceived" infringement on the forest, reconnect its parts, and re-stitch it in its surroundings in 2021 is ongoing, as stated by one member of Nahnoo (E. Saad, interview, March 9, 2021).

Away from Beirut's central spaces, the municipality "has either closed these parks, opening them intermittently, or privatized them like Sanayeh, or demolished them as in Tallet el-Khayyat, where a parking lot is now under construction," as indicated by one UN-Habitat social development coordinator (M. Nazzal, interview, October 28, 2020). Accordingly, UN-Habitat's role was to facilitate the provision of inclusive public spaces, especially in vulnerable neighborhoods, one being in Naba'a in the eastern suburb of Bourj Hammoud. This densely populated neighborhood has diverse Lebanese communities and also hosts Syrian refugees and migrant workers, all living in poor conditions, where even streets barely serve as public spaces. A project to co-design a much-needed public space in this neighborhood was completed in 2016, where UN-Habitat moderated the collaboration of the municipality, residents, and refugees (Mady, 2019). In 2020, the conditions of shared identity and collaboration were missing, with the municipality's priorities shifting after the Beirut port explosion. One member considered the space as "simply not convenient at this time and in this location....There is a conflict in this space," referring to the schism among conceived, lived, and perceived spaces (G. Krikorian, interview, October 28, 2020). UN-Habitat considered the disengagement by the municipality and residentsconditions necessary to produce social space-as detrimental to the neighborhood. One resident who had actively worked to realize this space considered that it now "lacks liveliness, it is used but not much, not as
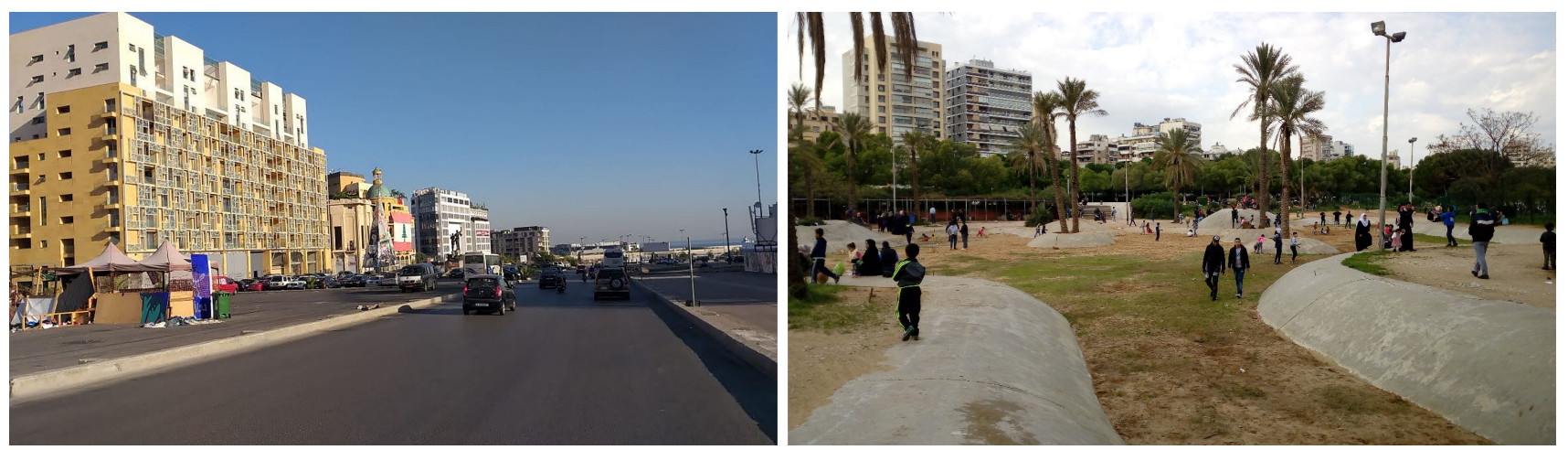

Figure 4. Martyrs Square and the Pine Forest turn into social spaces when activated by people's practices and their appropriations with signs, symbols and objects, and placemaking. 
expected," and that neglecting it is "discriminatory" in a neighborhood which "gathers all sects and nationalities" and where social practices still occur ( $\mathrm{H}$. Fakhreddine, interview, October 30, 2020).

Responding to the lack of social spaces on a larger scale, other initiatives were implemented and included the right to shared mobility across communities, represented by the Riders Rights NGO. In 2015, a map of the existing bus system, indicating perceived spaces along routes and stops, was generated in collaboration between the NGO founders and riders, raising awareness on this social space within Greater Beirut (C. Faraj, interview, March 3, 2021; see Figure 5). Starting in 2012, several civic society initiatives mobilized campaigns for the right to access the sea and, more specifically, in 2013 , this included the protection of the Dalieh cape from "conceived" projects neglecting its social practices (Saksouk-Sasso, 2015). Marginalized spaces in refugee camps were the concern of activists in terms of maintaining "perceived" play areas (Public Works Studio, 2018). Several initiatives set up temporary marketplaces for encounter after 2005 (Mady \& Chettiparamb, 2016) and, more recently, in 2019, an initiative supporting livelihoods provided a temporary garage souq in the Mar Mikhael area (J. Zahawi, interview, November 26, 2020; see Figure 6). Other initiatives to reclaim, appropriate, or activate urban social spaces were documented across Beirut (Mazraani, 2020).

\subsection{An Indication of Inhabitants' Perspectives on Beirut's Public Spaces}

Further to the explanation of space production in Beirut specifically after 2005, the online questionnaire survey conducted in September 2021 indicated inhabitants' views, knowledge, and practices regarding the city's public spaces relative to their gender, age, and place of residence (Table 1 ). Almost $22 \%$ of respondents in the age range of 51-65 or above indicated that they lived through the civil war, while about $41 \%$ were in the age range $31-50$, or were born during the war period, and the rest were born after the war ended. Respondents indicated their familiarity and practices within the former demarcation buffer comprising Martyrs Square, Damascus Road, the Pine Forest, and other spaces they frequent (Figure 1), the state of public spaces within their neighborhoods, their preferences for public space symbolism, and the activities they practice in public spaces.

About $53 \%$ of respondents aged under 31 considered Damascus Road to be unfamiliar or just another street. The remaining, mostly above 31 years of age, identified it as a famous street. This suggests these respondents' association of the street with the war-time demarcation line. Martyrs Square has been visited during demonstrations by about $44 \%$ of respondents of all ages and places of residence, while $32 \%$ go there to be in the centertheir ages ranging above $31-$ and about $23 \%$ do not visit
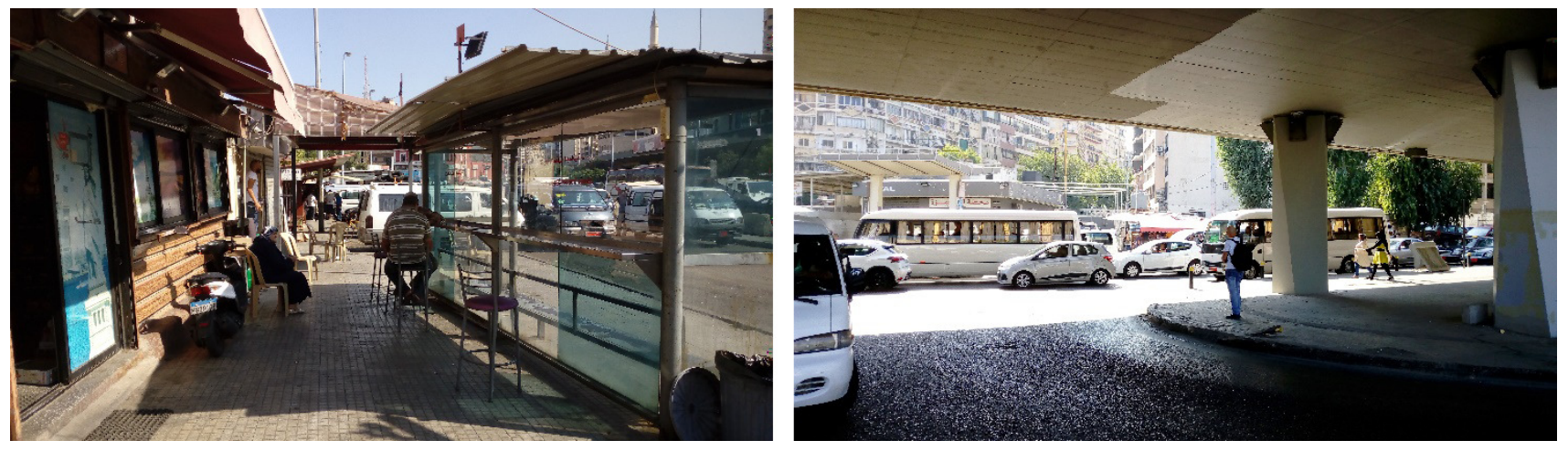

Figure 5. Mobility as social space, identified through riders' practices, available conceived spaces, and lived spaces of the informal transportation system at the Cola Roundabout.
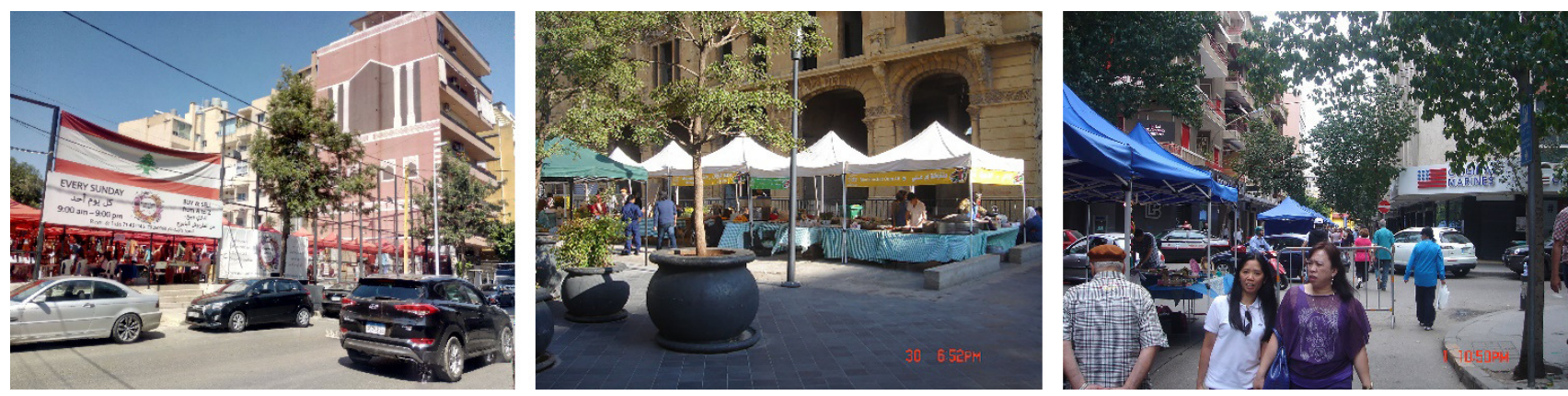

Figure 6. Temporary marketplaces reflecting social spaces in (left to right) Mar Mikhael, city center in Beirut Souks, and Makdissi Street. 
Table 1. Description of the questionnaire survey.

Developing the survey

The questionnaire was designed to collect data on:

- Respondents' profiles (gender, age, and place of residence);

- Respondents' familiarity and experiences in the former demarcation line's public spaces (Martyrs Square, Damascus

Road, and the Pine Forest);

- Their perceptions and practices regarding public spaces within Beirut and Greater Beirut;

- Availability of public spaces within their neighborhoods;

- Respondents' public space preferences regarding symbolism and activities performed in them.

Administering the survey

- The survey was sent to a WhatsApp list of 68 individuals for further dissemination and was completed by

122 respondents;

- Questionnaire instructions indicated the survey's content and purpose and estimated completion time;

- A consent form was included in the online questionnaire, to be selected by the respondent;

- Duration: The questionnaire survey was available for one week, including a weekend.

Respondent profiles

Gender distribution $58.2 \%$ female, $41.8 \%$ male.

Age distribution

$5.7 \%$ above $65,17.2 \%$ between 51 and $65,41.8 \%$ between 31 and 50, 30.3\% between 21 and 30 , and $4.9 \%$ between 18 and 20 .

Place of residence

distribution

28.7\% outside Greater Beirut, 28.1\% within Greater Beirut, and 43.2\% in Beirut. The latter are distributed as $25.2 \%$ from the western part and $18.0 \%$ from the eastern part.

it. The first category confirms how this space became a destination following its activation through demonstrations, while the second category suggests their association with the square as an everyday public space. In addition to Martyrs Square, the city center is mainly a destination for its waterfront space at Zaitouna Bay and the Beirut Souks shopping center, while few respondents mentioned other squares and parks within the center. These respondents vary in age and place of residence, suggesting that the purposes of their visits are not necessarily related to the center's conceived but rather the perceived public spaces. About $61 \%$ of respondents, mostly aged above 31 , do not visit or have not visited the Pine Forest, and about $26 \%$ coming from different suburbs and parts of Beirut visit it to be in contact with nature or practice sports. Two respondents in the age range 51-65 consider the Pine Forest far away from their activities, although there is public transportation from where they live in west Beirut, while three respondents of different age groups living in administrative Beirut are unaware of it, and five respondents think it is closed. The responses signal how the Pine Forest is not part of the spaces used by some inhabitants who lived through the war, while others are unaware of Nahnoo's campaigns.

Regarding visited and preferred spaces in and around Beirut, the sea waterfront and streets remain the main attractions, with $27 \%$ and $30 \%$ of respondents referring to them, respectively. Almost an equal number of respondents, each with $20 \%$, refer to private spaces or malls and the city center as destinations. Other respondents refer to parks and the Pine Forest as attractions, with $17 \%$ and $13 \%$, respectively. Only $2.5 \%$ referred squares, while $19 \%$ indicated no public spaces (these are respondents who do not walk), and around $6.6 \%$ referred spaces outside Beirut. Respondents who do not walk could indicate limited walkability and poor quality of streets as conceived spaces, and generally responses indicated the scarcity of conceived public spaces. Regarding destinations, respondents living within administrative Beirut tend to visit its spaces, including the center, and few visit spaces in Greater Beirut. Respondents within the eastern and western suburbs tend to visit Beirut in general, mainly the waterfront in the center, the Corniche in the western part, and spaces within their suburbs. This reflects what was stated in the literature on the limited mobility across areas and communities, yet this requires further validation with a more representative sample.

When replying to the availability of spaces within neighborhoods, about $48 \%$ of respondents indicated having only streets and about $24 \%$ referred to vacant lots and parking lots. Only $10 \%$ referred to parks and the remaining $20 \%$ referred to highways, unwalkable streets, squares, privately provided open spaces, or spaces outside Beirut. Among respondents who indicated streets as public spaces, half of them live in administrative Beirut, while only $24 \%$ come from Greater Beirut, and the rest from outside. This denotes the scarcity of conceived public spaces beyond the city center.

When asked about symbolism, in terms of preferred sculptures in public spaces or having them as green spaces, about $57 \%$ of respondents preferred having only green spaces, almost $40 \%$ preferred art or Lebanese figures, only $4 \%$ preferred seeing religious figures, and none 
indicated political figures. This signals an aversion from lived spaces symbolizing politico-sectarian identities and the need for less programmed civic, social spaces, lending themselves to improvisation.

Regarding activities they perform in public spaces, almost $27 \%$ of respondents living in different parts of Beirut, and from different age groups-but mainly aged 21-30-use them to sit outdoors, and $25 \%$ to socialize and interact with others. Almost $19 \%$ of respondents use public spaces to practice outdoor sports, $11 \%$ to commute on foot, and the remaining indicated a combination of all these activities. This suggests people's wish for encounter, interaction, and presence within the city's social spaces.

Other comments shedding light on the state of public spaces indicated the need for safer, green spaces within the city, echoing the scarcity of conceived public spaces in Beirut. Some respondents emphasized that streets in Beirut are not walkable, requiring people to find ways to cross them, or as one respondent stated: "Generally, Beirut is not made for pedestrians. It's a pity." One respondent living outside Beirut, in the age range 31-50, stated: "We have [a] big lack of public spaces and that limits social interaction. I really believe it is done on purpose. That is why we started an intervention project in Karantina." This indicates efforts done for the production of social spaces and complements what other respondents commented regarding the need for more public spaces, or as another respondent said: "More open spaces [are] needed in Greater Beirut and not just in the city center!"

\section{Conclusion}

This article explored the evolution, transformations, and adaptations of Beirut's public spaces since the $1800 \mathrm{~s}$ until the turbulences of 2019. Lefebvre's (1991) space production triad provided the framework for understanding resonances and dissonances across "conceived, lived, and perceived" spaces, and the conditions for providing spaces that enable co-existence of diverse social practices. This reading of Beirut's public spaces highlighted how inherited "social practices" tinted the imported "conceived" space models and the conditions that led to their transformation as "lived and perceived" social spaces during the Ottoman, French mandate, and Republic periods. The war caused the annihilation of public spaces and dominance of "representational" spaces, reflecting Beirut's politico-sectarian fragmentation. The securitization and commodification of urban spaces had adverse implications on "perceived" spaces for everyday life practices, leading to contestations and exclusions. In the post-war period, conditions leading to the production of social spaces were analyzed. On the one hand, divisions, control, spatial fragmentation, and inequitable attention to marginal areas deterred the production of social spaces. On the other hand, organized collaboration and consensus building enabled the under- standing of differences and allowed for their co-presence by constructing common identities related to civic rights and place-based needs. This was manifested in examples of reclaiming existing spaces or co-designing new ones, and was corroborated through the questionnaire survey responses. Although further empirical work is required to validate these responses, they nevertheless highlight the importance of investigating the state of social spaces within present time Beirut. The dire need to produce alternative social spaces that facilitate interaction will remain as Beirut continues to witness unprecedented instability.

\section{Acknowledgments}

The author would like to thank the reviewers for their valuable comments, Jessica Lahoud for her support with the map, Laura Smith for the proofreading, and all questionnaire survey respondents.

\section{Conflict of Interests}

The author declares no conflict of interests.

\section{References}

Ababsa, M. (2002). Idéologies territoriales et pratiques urbaines des riverains de l'ancienne ligne de démarcation de Beyrouth [Territorial ideologies and urban practices of streams of the ancient demarcation line in Beirut]. In B. Reitel, P. Zander, J. L. Piermay, \& J. P. Renard (Eds.), Villes et frontières [Cities and borders] (pp. 14-25). Anthropos.

Albrecht, M. (2017). Krieg der Symbole. Politische Parteien und Parteikultur im Libanon (1975-2015) [The war of symbols: Political parties and party culture in Lebanon (1975-2015)]. LIT Verlag.

Albrecht, M. (2020). Clash of memories: Commemorating the civil war in Lebanon. Public History Weekly, 8(6). https://doi.org/10.1515/phw-2020-16551

Bollens, S. A. (2012). City and soul in divided societies. Routledge.

Bou Akar, H. (2012). Contesting Beirut's frontiers. City and Society, 24(2), 150-172.

Bou Akar, H. (2018). For the war yet to come: Planning Beirut's frontiers. Stanford University Press.

Brown, A. (2006). Urban public space in the developing world: A resource for the poor. In A. Brown (Ed.), Contested space: Street trading, public space and livelihoods in developing cities (pp. 17-36). ITDG Publishing.

Carmona, M., de Magalhães, C., \& Hammond, L. (Eds.). (2008). Public space: The management dimension. Routledge.

Carr, S., Francis, M., Rivlin, L. G., \& Stone, A. M. (1992). Public space. Cambridge University Press.

Cutts, B. B., \& Minn, M. (2018). Dead grass: Foreclosure and the production of space in Maricopa County, Ari- 
zona. Urban Planning, 3(3), 16-25.

Davie, M. (1999). Les places publiques de Beyrouth au tournant du XIXe siècle [Beirut's public spaces at the turn of the 19th century]. London National Museum News, 1999(9), 23-28. https://cutt.ly/4mKPtUj

Davie, M. (2001). Beyrouth, 1825-1975: Un siècle et demi d'urbanisme [Beirut, 1825-1975: A century and a half of urbanism]. Order of Engineers and Architects.

Davie, M. F. (1991, July 18-21). Demarcation lines in contemporary Beirut [Paper presentation]. Second International Boundaries Research Unit Conference, Durham, UK.

Davie, M. F. (1993, July 8-11). A post-war geography of Beirut [Paper presentation]. EURAMES Conference, Warwick, UK.

Deeb, L., \& Harb, M. (2013). Leisurely Islam: Negotiating geography and morality in Shi'ite South Beirut. Princeton University Press.

Dorsch, S. (2013). Space/time practices and the production of space and time: An introduction. Historical Social Research/Historische Sozialforschung, 38(3), 7-21.

Dumont, P. (2013). Salonica and Beirut: The reshaping of two Ottoman cities of the Eastern Mediterranean. In E. Ginio \& K. Kaser (Eds.), Ottoman legacies in the contemporary Mediterranean: The Balkans and the Middle East compared (pp. 189-208). The European Forum at the Hebrew University.

Fawaz, M. (2014). The politics of property in planning: Hezbollah's reconstruction of Haret Hreik (Beirut, Lebanon) as case study. International Journal of Urban and Regional Research, 38(3), 922-934.

Fawaz, M., Harb, M., \& Gharbiyeh, A. (2012). Living Beirut's security zones: An investigation of the modalities and practice of urban security. City \& Society, 24(2), 173-195.

Fawaz, M., Harb, M., \& Gharbiyeh, A. (Eds.). (2009). Beirut: Mapping security. IABR.

Franck, K. A., \& Stevens, Q. (2007). Tying down loose space. In K. A. Franck \& Q. Stevens (Eds.), Loose space: Possibility and diversity in urban life (pp. 1-34). Routledge.

Gastil, R. W., \& Ryan, Z. (Eds.). (2004). Open: New designs for public space. Van Alen Institute.

Geha, C. (2019). Politics of a garbage crisis: Social networks, narratives, and frames of Lebanon's 2015 protests and their aftermath. Social Movement Studies, 18(1), 78-92.

Gehl, J. (1996). Life between buildings: Using public space (2nd ed.). Arkitektens Forlag.

Gehl, J., \& Gemzøe, L. (1996). Public space, public life. The Danish Architectural Press.

Genberg, D. (2002). Borders and boundaries in postwar Beirut. In A. Erdentug \& F. Colombijn (Eds.), Urban ethnic encounters: The spatial consequences (pp. 81-96). Routledge.

Hanf, T. (1993). Coexistence in wartime Lebanon: Decline of a state and rise of a nation. I. B. Tauris.
Hanssen, J. (1998). "Your Beirut is on my desk": Ottomanizing Beirut under Sultan Abdülhamid II (1876-1909). In P. Rowe \& H. Sarkis (Eds.), Projecting Beirut: Episodes in the construction and reconstruction of a modern city (pp. 41-67). Prestel.

Hanssen, J. (2005). Fin de siècle Beirut: The making of an Ottoman provincial capital. Clarendon Press.

Haydn, F., \& Temel, R. (Eds.). (2006). Temporary urban spaces: Concepts for the use of city spaces. Birkhäuser.

Healey, P. (2006). Collaborative planning: Shaping places in fragmented societies (2nd ed.). Palgrave Macmillan. (Original work published 1997)

Hebbert, M. (2005). The street as locus of collective memory. Environment and Planning D: Society and Space, 23(4), 581-596.

Hindi, N. (2015). On the making of public spaces in Beirut [Doctoral dissertation, University of Barcelona]. UB Digital Repository. https://cutt.ly/YmKPalD

Hou, J., \& Knierbein, S. (2017). City unsilenced: Urban resistance and public space in the age of shrinking democracy. Routledge.

Huybrechts, E. (1999). L'oubli de la ligne [Forgetting the line]. In E. Huybrechts \& C. Douayhi (Eds.), Reconstruction et réconciliation au Liban: Négociations, lieus publics, renouement du lien social [Reconstruction and reconciliation in Lebanon: Negotiations, public spaces, renewing the social bond] (pp. 209-220). Presses de l'Ipfo.

Kabbani, O. (1998). Public space as infrastructure: The case of the postwar reconstruction of Beirut. In P. Rowe \& H. Sarkis (Eds.), Projecting Beirut: Episodes in the construction and reconstruction of a modern city (pp. 240-259). Prestel.

Keilo, J. (2017). Reading French toponymic inscriptions in Beirut. Onoma, 52, 45-66. https://doi.org/10.34158/ ONOMA.52/2017/3

Keilo, J. (2020). The French map of Beirut. In A. Kent, S. Vervust, I. J. Demhardt, \& N. Millea (Eds.), Mapping empires: Colonial cartographies of land and sea. Seventh international symposium of the ICA Commission on the History of Cartography, 2018 (pp. 247-259). Springer.

Khalaf, S. (2002). Civil and uncivil violence in Lebanon: A history of internationalization of communal conflict. Columbia University Press.

Khalaf, S. (2006). Heart of Beirut: Reclaiming the Burj. Saqi.

Knierbein, S. (2015). Public space as relational counter space: Scholarly minefield or epistemological opportunity? In S. Knierbein \& C. Tornaghi (Eds.), Public space and relational perspectives: New challenges for architecture and planning (pp. 42-64). Routledge.

Knierbein, S., \& Tornaghi, C. (Eds.). (2015). Public space and relational perspectives: New challenges for architecture and planning. Routledge.

Kostof, S. (1992). The city assembled: The elements of urban form through history. Thames and Hudson. 
Landman, K. (2016). The transformation of public space in South Africa and the role of urban design. Urban Design International, 21(1), 78-92.

Landman, K. (2019). Evolving public space in South Africa: Towards regenerative space in the post-apartheid city. Routledge.

Landman, K. (2020). Inclusive public space: Rethinking practices of mitigation, adaptation and transformation. Urban Design International, 25(3), 211-214.

Larkin, C. (2012). Memory and conflict in Lebanon: Remembering and forgetting the past. Routledge.

Lefebvre, H. (1991). The production of space. Blackwell.

Loukaitou-Sideris, A., \& Banerjee, T. (1998). Urban design downtown: Poetics and politics of form. University of California Press.

Madanipour, A. (2003). Public and private spaces of the city. Routledge.

Madanipour, A. (2004). Marginal public spaces in European cities. Journal of Urban Design, 9(3), 267-286.

Mady, C. (2018). Public space activism in unstable contexts: Emancipation from Beirut's postmemory. In S. Knierbein \& T. Viderman (Eds.), Public space unbound: Urban emancipation and the post-political condition (pp. 189-206). Routledge.

Mady, C. (2019). UN-Habitat's engagement of residents, refugees and local authorities in a public space design process in Bourj Hammoud, Lebanon. In P. Aelbrecht \& Q. Stevens (Eds.), Public space design and social cohesion: An international comparison (pp. 158-177). Routledge.

Mady, C., \& Chettiparamb, A. (2016). Planning in the face of "deep divisions": A view from Beirut, Lebanon. Planning Theory, 16(3), 296-317.

Makakavhule, K., \& Landman, K. (2020). Towards deliberative democracy through the democratic governance and design of public spaces in the South African capital city, Tshwane. Urban Design International, 25(3), 280-292.

Matsubara, K. (2016). Gyoji Banshoya (1930-1998): A Japanese planner devoted to historic cities in the Middle East and North Africa. Planning Perspectives, 31(3), 391-423.

Mazraani, D. (2020). Urban vacant parcels as opportunities to reclaim public spaces in times of crises and austerity. Beirut Urban Lab. https://www. beiruturbanlab.com/en/Details/698/urban-vacantparcels-as-opportunities-to-reclaim-public-spacesin-times-of-crises-and-austerity

Monroe, K. V. (2011). Being mobile in Beirut. City and Society, 23(1), 91-111.

Monroe, K. V. (2017). Circulation, modernity, and urban space in 1960s Beirut. History and Anthropology, 28(2), 188-201.

Nagle, J. (2009). Sites of social centrality and segregation: Lefebvre in Belfast, a "divided city." Antipode, 41(2), 326-347.

Nemeth, J. (2010). Security in public space: An empirical assessment of three US cities. Environment and Plan- ning $A, 42(10)$, 2487-2507.

Nemeth, J., \& Hollander, J. (2010). Security zones and New York City's shrinking public space. International Journal of Urban and Regional Research, 34(1), 20-34.

Nkooe, E. S. (2018). Urban planning on Lefebvre and South Africa public spaces. Urban Planning, 3(3), 26-39.

Nucho, J. R. (2016). Everyday sectarianism in urban Lebanon: Infrastructures, public services and power. Princeton University Press.

Öztürk, P. K. (2006). Urban transformation of Ottoman port cities in the nineteenth century: Change from Ottoman Beirut to French mandatory Beirut [Master thesis, Middle East Technical University]. OpenMETU. https://etd.lib.metu.edu.tr/upload/12607699/ index.pdf

Papachristou, I. A., \& Rosas-Casals, M. (2019). Maximising the degree of user choice: A simple tool to measure current levels of quality of life in urban environments. Urban Planning, 4(2), 207-222.

Public Works Studio. (2018, January 24). Camp Radio [Workshop]. https://publicworksstudio.com/en/ projects/camp-radio

Rydin, Y. (2011). The purpose of planning: Creating sustainable towns and cities. Policy Press.

Saksouk-Sasso, A. (2015). Making spaces for communal sovereignty: The story of Beirut's Dalieh. The Arab Studies Journal, 23(1), 296-318.

Salam, A. (1998). The role of government in shaping the built environment. In P. Rowe \& H. Sarkis (Eds.), Projecting Beirut: Episodes in the construction and reconstruction of a modern city (pp. 122-133). Prestel.

Salama, A., \& Wiedmann, F. (2013). The production of urban qualities in the emerging city of Doha: Urban space diversity as a base for investigating the "lived space." International Journal of Architectural Research, 7(2), 160-172.

Saliba, R. (1997). The mental image of Downtown Beirut, 1990: A case study in cognitive mapping and urban form. In M. F. Davie (Ed.), Beyrouth: Regards croisés [Beirut: Contrasting perspectives] (pp. 305-349). URBAMA.

Saliba, R. (1998). Beirut 1920-1940: Domestic architecture between tradition and modernity. Order of Engineers and Architects.

Sinno, W. (2020). How people reclaimed public spaces in Beirut during the 2019 Lebanese uprising. Public Space, 5(1) 193-218.

Staeheli, L. A., \& Thompson, A. (1997). Citizenship, community and struggles for public space. Professional Geographer, 49(1), 28-38.

Tabet, J. (1996). Al-I'maar Wal-Masslaha Al-A'amah [Reconstruction and the public good]. Dar Al-Jadid.

Tornaghi, C. (2015). The relational ontology of public space and action-oriented pedagogy in action: Dilemmas of professional ethics and social justice. In S. Knierbein \& C. Tornaghi (Eds.), Public space and rela- 
tional perspectives: New challenges for architecture and planning (pp. 17-41). Routledge.

Tozoglu, A. E. (2019). Power, conflict and negotiation between the agents: An alternative vision for contestation on the public space in the late Ottoman empire. Planning Perspectives, 36(1), 21-48.

Traboulsi, F. (2012). A history of modern Lebanon (2nd ed.). Pluto Press.

Verdeil, E. (2011). Beyrouth et ses urbanistes: Une ville en plans (1946-1975) [Beirut and its urbanists: A city in plans (1946-1975)]. Presses de l'Ifpo.

Verdeil, E. (2012). Michel Ecochard in Lebanon and Syria (1956-1968): The spread of Modernism, the building of the independent states and the rise of local professionals of planning. Planning Perspectives, 27(2), 249-266.

Véron, O. (2016). Contesting the divided city: Arts of resistance in Skopje. Antipode, 48(5), 1441-1461.

Wolf, G., \& Mahaffey, N. (2016). Designing difference: Coproduction of spaces of potentiality. Urban Planning, 1(1), 59-67.

Yahya, M. (1993). Reconstituting space: The aberration of the urban in Beirut. In S. Khalaf \& P. Khoury (Eds.) Recovering Beirut: Urban design and post war reconstruction (Vol. 47, pp. 128-166). Brill.

\section{About the Author}

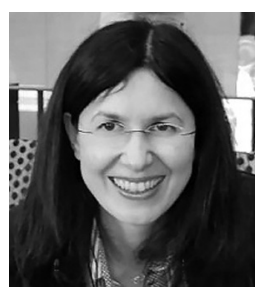

Christine Mady is an associate professor of urban planning in the Department of Architecture at the Ramez G. Chagoury Faculty of Architecture, Arts and Design of the Notre Dame University-Louaize, Lebanon. She is also a member of the UKRI International Development Peer Review College. In 2014, she was awarded the Urban Studies Foundation (USF) International Fellowship. Her research examines public spaces within contexts of instability, their roles in everyday life, and their potentials for social integration. 